\title{
Development of Test Instruments and Audio Based Concentration Measurements for Blind Students in Bandung, Indonesia
}

\author{
Beltasar Tarigan*, Ahmad Zulfikar, Lilis Komariyah \\ Departemen Pendidikan Olahraga \\ Universitas Pendidikan Indonesia \\ Bandung, Indonesia \\ *beltasartarigan@upi.edu
}

\begin{abstract}
The purpose of this study was to compile an audiobased concentration test and measurement instrument for blind students in the city of Bandung, due to the lack of valid and reliable test and concentration measurement instruments for blind students. This research uses Research \& Development ( $R$ \& D) method. The subjects of this study were blind students aged 13-15 years in the city of Bandung. The sampling technique used purposive sampling technique, with the number of 63 blind students as samples. The results of this study indicate that: (1) Formation of hardware and working systems of test instruments and concentration-based audio measurements for blind students. (2) The results of the data analysis showed that the validity test using the Pearson Product Moment formula (r-PM) obtained very high validity criteria, while the reliability test using the Alpha formula obtained very high degree of reliability criteria. Conclusion, the compilation of hardware and work systems for audio-based test and concentration measurement instruments for blind students who have been tested valid and reliable.
\end{abstract}

Keywords-instrument; concentration; audio based; blind student

\section{INTRODUCTION}

Education begins when humans are born and last for life, every layer of society has the same rights to get a decent education, including Children with Special Needs (ABK). Physical education is part of education that has the same goals as other subjects, namely developing the ability and forming dignified characters in order to educate the life of the nation, but physical education has its own way and uniqueness in achieving these goals. Physical education is the process of education through physical activity, games or sports that are chosen to achieve educational goals [1]. ABK students also have the right to receive physical education specifically in accordance with the type of obstacle they have. The physical education designed specifically for $\mathrm{ABK}$, namely adaptive physical education. Adaptive physical education is a very strategic means in an effort to increase physical growth and development, movement, social and intellectual skills of disabled students [2]. Improving the quality of the physical education process in exceptional schools is very important to instill a positive attitude towards the limitations of their abilities, both physically and mentally so that students are able to socialize with the environment and have confidence and self-esteem.

There is a classification of ABK adjusted according to the obstacle or type of disability that is owned by students, namely mentally disabled, disabled, blind, deaf and speechless. Blind people are a type of disability with an impairment of one's vision, the Indonesian Blind Association suggests the definition of blind people, those who have no vision at all (totally blind) to those who still have remaining vision but are unable to use their vision to read ordinary sized writing 12 points in normal light even though they are assisted with glasses (not alert). Furthermore visual impairment means blindness in the eyes, so that they cannot see and their effects are detrimental to the child's appearance during the education period [3].

Blindness certainly provides obstacles for students who suffer from it, especially in learning especially to understand the concepts intended by the teacher. In these conditions, concentration has an important role to focus on learning activities, with good concentration, these obstacles can be minimized.

Concentration for blind students is important along with their limitations which are difficult to receive visually. Stimulus through auditive or audio touches and symbols is the most optimal thing for blind students to understand what is conveyed by the teacher. Especially auditive or audio symbols because the reception of stimuli is carried out through the auditory senses, thus helping them to concentrate. Concentration is the concentration of the mind on a matter by excluding all other unrelated things [4]. In learning physical education concentration means concentration of thought on the task of motion instructed without regard to other things that are not needed.

A person's concentration can be said to be good or bad based on data obtained through tests and measurements using an instrument. Instruments can be defined as tools that meet academic requirements, so that they can be used to measure and collect data for a variable. Data collection instrument is a tool chosen and used by researchers in collecting data so that the activity becomes systematic and can be facilitated by it [5]. 
The meaning of instruments in the scope of research, research instruments are a tool used to measure observed natural and social phenomena [6]. Data collection using certain instruments will be described and used to test the hypotheses proposed in the study.

At present to measure a person's concentration level can be done using a test instrument and a Grid Concentration Test measurement. But it is unfortunate that the instrument does not apply if applied to blind students. This is because the stimulus provided by the Grid Concentration Test instrument in the form of visual and very clear is impossible to be done by blind students. Visual impairment directly lowers the quality of movement and motoric perceptual ability because a person is unable to perceive visual stimuli normally [7]. In other words, normal student concentration measurement instruments are inappropriate if used to measure the concentration of blind students, because of differences in characteristics in receiving a stimulus and responding.

Tests and measurements are unity, because in order to obtain data that is appropriate for the purpose of measurement, the object being measured must be in accordance with the purpose of measurement itself. Tests are systematic procedures that are made in the form of tasks that are standardized and given to individuals or groups to be done, answered, or responded to in writing, verbal or deed. The test is a series of objective procedures to obtain data to explain the results to be known, the test is a tool or procedure used to find out or measure something in an atmosphere by means and rules predetermined rules [8].

Tests and measurements are inseparable and interconnected. Measurement has a meaning that is useful for determining information about an object precisely [9]. In this case educators estimate student achievement by reading or observing what students do, observing their performance, hearing what they say, and using their senses such as seeing, hearing, touching, kissing, and feeling. Measurement has two main characteristics, namely: 1) the use of certain numbers or scales; 2) according to a certain rule or formula. The test is a method that can be used or procedures that need to be taken in the framework of measurement and assessment in the field of education in the form of assignments or a series of tasks in the form of questions that must be answered or commands that must be done by testee, so that on the basis of data obtained from the measurement results can be generated values that symbolize the behavior or achievements of testee [10].

Measurement in the field of education means measuring the attributes or characteristics of certain students. In simple terms, measurements are quantitative scores derived from tests. Based on the above theory, it can be understood simply that tests and measurements are a tool to collect data or information about what you want to achieve.

Literally Audio comes from the audible word, meaning the sound that can be heard naturally by the human ear. The ability to hear humans is in the area of frequency between 20 to 20,000 Hertz. Audio-based media has a uniqueness in which the message conveyed is expressed in auditive symbols both verbally (words / verbally) and non-verbally which are then absorbed and can only be accepted by the sense of hearing.
This uniqueness from Media Audio is a medium that the delivery of its message can only be received by the auditory senses. The message or information to be conveyed is poured into auditive symbols in the form of words, music and sound effects [11]. The process of communication and learning based on audio is always related to listening and listening.

The definition of listening is that physiologically listening is the process by which sound waves entering the outer ear radiated to the eardrum are converted into mechanical vibrations in the middle ear, and converted in the inner ear into signal (impulse) that moves towards the brain. Psychologically listening begins with one's awareness and attention about letters or patterns of conversation (receiving), followed by identification and introduction of specific auditory signals (deciphering meaning), and ending with understanding (understanding) [12].

The principle of the use and selection of a media is not how expensive or how sophisticated the media used, but how good the effectiveness and efficiency provided by the media. The suitability of a media with the characteristics and level of ability of students must be considered, not too complicated and not too easy. Audio characteristics as a medium for conveying messages are very suitable with the characteristics possessed by blind students, because the stimulus produced can only be received through hearing. Margins, column widths, line spacing, and type styles are built-in; examples of the type styles are provided throughout this document and are identified in italic type, within parentheses, following the example. Some components, such as multi-leveled equations, graphics, and tables are not prescribed, although the various table text styles are provided. The formatter will need to create these components, incorporating the applicable criteria that follow.

\section{METHOD}

\section{A. Research Method and Samples}

In this study researchers used Research \& Development ( $R$ $\&$ D) research methods, where this method is used to produce certain products. The product referred to in this study is an audio-based concentration test and measurement instrument for blind students. The sample in this study were 63 blind students aged 13-15 years in Bandung City using purposive sampling technique.

\section{B. Product Design}

Researchers designed the design of audio-based concentration test and measurement tools for blind students based on the information collected as follows:



Fig. 1. Product design 
Information:
$\mathrm{A}=$ Power outlet, to turn on and turn off the appliance
$\mathrm{B}=$ Button to start the test
$\mathrm{C}=$ Speaker that issues an audio-based stimulus
$\mathrm{D}=\mathrm{LCD}$ as the score viewer obtained by testee
$\mathrm{E}=\mathrm{LED}$ as an indicator for what color tester is being given by the device

\section{$\mathrm{F}=$ Push Button to respond to test items \\ $\mathrm{G}=\mathrm{USB}$ port to recharge}

Instruments designed by researchers are not mere coincidences, but researchers have analyzed rationally based on empirical facts why these instruments are made in such a way as follows:

- This instrument uses audio as a stimulus because it matches the characteristics of the dominant blind person using his sense of hearing and sense of touch to carry out daily activities.

- The eyes of blind students are closed with a view to generalizing blindness to total blindness and low vision. So that their condition becomes the same, which is not able to see in total.

- This instrument uses color as audio (red, yellow, and green), because most blind students do not have experience in color, so this is a new thing for them. Different from determining the direction / position they have learned for everyday mobility such as "left", "middle", "right", "front", "back" "top" "down" etc.

- This tool is set automatically to provide different stimuli for each test carried out, this is so that the sequence of the stimulus cannot be memorized by blind students.

- One button (Push Button) has been set automatically only to answer 1 color. So that if a student presses the button incorrectly, this tool will not continue to the next stimulus and the time will continue until the student answers correctly.

- This instrument has been set up to automatically record the student's speed in response to 10 audio stimuli and the average speed of answering them. This is intended to make it easier to collect data and to take advantage of the development of science and technology.

\section{Data Collection Technique}

In this research data collected by testing all samples with test and retest techniques. The test uses an instrument that has been made by researchers to measure the level of concentration for blind students. In the test and retest technique is do by testing 2 times to the same person, the same instrument but different times.

\section{Data Analysis}

In this study statistical data analysis was used to test the validity of test instruments and concentration measurement using Pearson Product Moment, and to test the reliability of test instruments and concentration measurements of blind students using the Test \& Retest method with the Alpha statistical formula. Data was obtained by collecting directly into the field through a test using a tool that was made by the researcher.

\section{RESULTS}

\section{A. Hardware Manufacturing}

Researchers realize the product design concepts that have been made before, this tool is designed portable to be more effective and efficient. By making this device portable, the mobility of this tool also becomes easier, one of which is that it can be used when it is in a position far from the source of the electric current.



Fig. 2. Front Look.

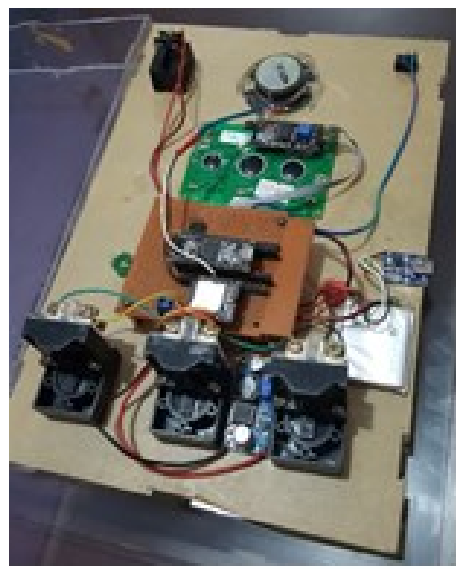

Fig. 3. Inside Look.

So that the above test equipment can run in accordance with the concepts and designs that have been made, it requires some hardware to support the function of the test equipment, namely:

- Arduino Nano

Arduino Nano is a small microcontroller development board, where the microcontroller functions as the brain to process data because in the microcontroller chip contains all the basic components of a computer on a small scale. 




Fig. 4. Arduino Nano.

\section{- DFPlayer Mini}

DFPlayer Mini is a small and low sized MP3 module with simplified output directly to the speaker. DFPlayer connects a complex decoding module perfectly, which supports audio formats in general such as MP3, WAV, WMA. DfPlayer Mini is used to play the sound of stimulus randomly.

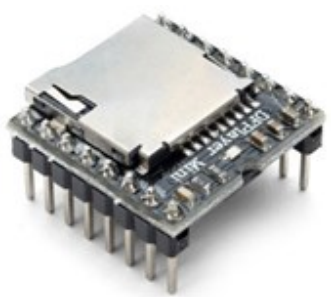

Fig. 5. DF Player Mini SKU:DFR0299.

- LCD (Liquid Cristal Display)

LCD (Liquid Cristal Display) functions as a data viewer in the form of characters, letters, numbers or graphics. In this tool the LCD functions as a flat screen that displays the word greeter and presents a score from the test that has been done by testee.



Fig. 6. LCD $16 \times 4$.

- LED (Light Emitting Dioda)

LED stands for Light Emitting Diodes, a diode that can emit light when it gets forward bias. In this tool the LED serves as an indicator for the tester, what stimulus / color is being given to testee.

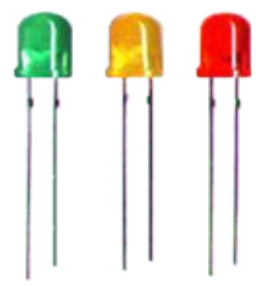

Fig. 7. LED 3 Colors (Green, Yellow, Red).

\section{- Li-Po Battery}

Lithium Polymer batteries or commonly referred to as LiPo are one type of battery that is often used in the world of electronics. In this device the Li-Po battery used is a Li-Po 1 cell battery which means that the battery in this device has a voltage of 3.7 volts battery. This battery functions to store power so that the test device becomes portable and becomes more efficient.

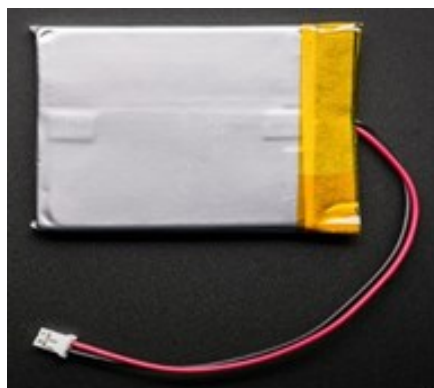

Fig. 8. Li-Po Battery.

- Battery Charger Module

Simply put, this charger module functions to charge if the battery used is used up. This charger module can be used to charge 1 Lithium battery or several Lithium batteries connected in parallel. There are 2 indicator lights, namely red indicates that it is charging and blue indicates that the battery is full.

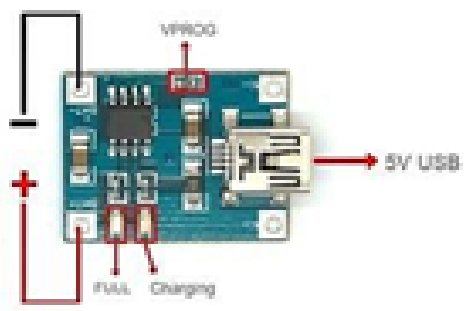

Fig. 9. Battery Charger Module.

- SD Card

Secure Digital (SD) is a flash memory card format. MicroSD is a non-volatile memory card developed by the SD Card Association that is used in portable devices. In this measuring instrument, researchers use a MicroSD type SD Card with a capacity of $2 \mathrm{~GB}$ which serves to store audio / audio data that will be used as a stimulus.

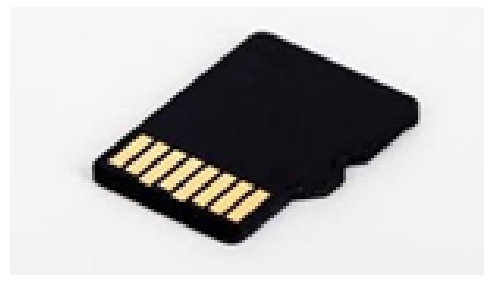

Fig. 10. Micro SD. 


\section{- Push Button}

Push buttons are the most common form of switch from manual controllers found in industry. In this tool the push button functions as a tool to respond to the stimulus provided by pressing.

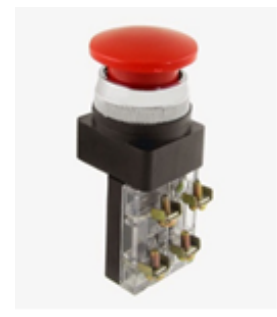

Fig. 11. Push Button.

\section{- Speaker}

Speaker / loudspeaker is a means of sound reproduction or music. A good speaker must be able to reproduce sounds like the original, both in terms of sound color, tone range, etc. In this tool the speaker functions as a means of sound stimulus given to testee.

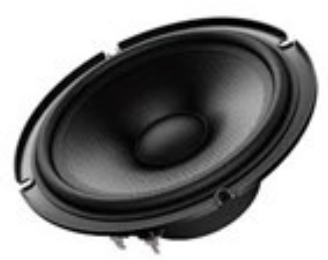

Fig. 12. Speaker.

\section{- Acrylic}

Acrylic is a kind of plastic that resembles glass, but has properties that make it superior to glass, acrylic is a super hard plastic sheet. The color is not fast enough and its light weight becomes superior. In this tool acrylic is used as home or home for every component that exists.



Fig. 13. Acrylic.

\section{- Blindfold}

Blindfold is simply a blindfold. In this study blindfold becomes a separate device but has an important role in the preparation of this instrument. The blindfold that the researchers used was made from jelly material coated with a soft cloth so it was comfortable to use.

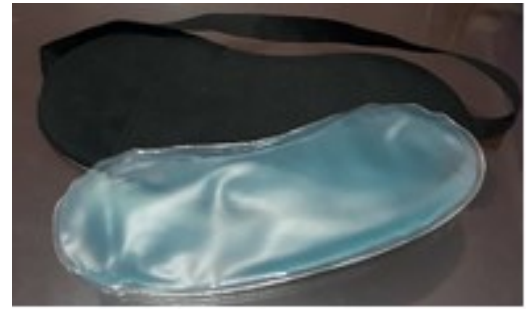

Fig. 14. Blindfold Jelly.

\section{B. Work System}

This tool works to measure the level of concentration of blind students. The working system of this tool is related to stimulus and response, where this tool will provide a stimulus for blind students as testee in the form of sound or audio (red, yellow, green). Then the stimulus will be received through the sense of hearing by students with visual impairment and students will respond through their sense of touch by pressing the push button according to the stimulus received.

The output of this tool is the speed of blind students in responding to the 10 stimuli given, so that the data unit is seconds. The results will be displayed on the LCD automatically when students have completed the test.

\section{Test Instructions}

In order for this instrument to provide optimal results in measuring the level of concentration of blind students, researchers have made the following test instructions:

- Students sit as comfortably as possible facing audiobased concentration gauges for blind students.

- The tester closes the eyes of blind students using an eye patch made of jelly coated with a soft cloth, so that it is comfortable to use.

- Tester describes the purpose and purpose of this tool is made, the type of stimulus provided by this tool, and the procedure for responding to these stimuli.

- If the student understands, the tester will turn on the device by pressing the power socket. Automatically the LCD will turn on and the Speaker will release the "Welcome" sound.

- The ster presses the "ON" button to start the test and the speaker will release the "Start" sound. The time starts automatically and will be displayed on the LCD.

- Automatically this tool will issue an audio-based stimulus with the sound "Red", "Yellow" or "Green" randomly 10 times.

- Students are tasked with receiving the stimulus through the sense of hearing and responding through the sense of touch by pressing the Push Button that matches the intended stimulus.

- If students press the button incorrectly, this tool will not provide the next stimulus and the time will continue to 
run until the student presses the button that is meant correctly.

- When the test is complete, this tool automatically records the student's speed in response to 10 audiobased stimuli that will be displayed through the LCD screen along with the sound "Score".

\section{DISCUSSION}

The product design in this study was produced based on empirical facts that occurred in the field regarding the characteristics of blind students. Researchers also conducted several rational analyzes supported by the theory of experts so that the products produced could truly be used and beneficial to the world of education in Indonesia.

Data collection is done by testing the product to each sample, here the researchers found new reactions shown by blind students most of them were very curious about this product. Not even a few blind students ask how to make it, for what purpose and much more. Often they ask for time to touch and feel the entire product component for longer.

The results of the validity test using Pearson Product Moment with the help of SPSS 20.0 for Windows application get the value of r-PM $=0.852$ then the validity criteria based on the criteria table are included in the criteria for high validity. Then, the significance value obtained is 0,000 . Because of sig. $<0.05$ then $\mathrm{H} 0$ is rejected, meaning that there is a significant relationship between the test and retest instruments tested. In other words, the instrument being tested is said to be valid.

The calculation of the next analysis is the reliability test using the Test \& Retest method and the Alpha statistical formula with the help of SPSS 20.0 for Windows application obtained a degree of reliability of 0.912 so that it can be interpreted into the classification coefficient that the instrument including very high degree of reliability criteria [13]. By using a sample of 63 people, then the df used in rtable is 61, the rtable obtained is 0.2480 . Because $\mathrm{r}$ count $=0.912 \geq \mathrm{r}$ table $=$ 0.2480 , then the instrument being tested is said to be reliable.

The findings of this study indicate that audio-based test and concentration measurement instruments for blind students are valid and reliable to measure the concentration of blind students aged 13-15 years in the city of Bandung.

\section{CONCLUSION}

Based on data processing and research results, it is concluded as follows:

- The composition of Hardware and the working system of test instruments and concentration-based audio measurements for blind students.

- The compilation of valid and reliable audio based test and concentration measurement instruments for blind students with very high criteria of validity and reliability.

\section{REFERENCES}

[1] A. Mahendra, Falsafah Pendidikan Jasmani. Bandung: FPOK UPI, 2009.

[2] B. Tarigan, Optimalisasi Pendidikan Jasmani dan Olahraga Berlandaskan Ilmu Faal Olahraga. Bandung, 2009

[3] B. Tarigan, Modul Pendidikan Jasmani Adaptif. Bandung: FPOK UPI, 2008.

[4] Slameto, Belajar \& Faktor-Faktor Yang Mempengaruhi. Jakarta: Rineka Cipta, 2013.

[5] S. Arikunto, Manajemen Penelitian. Jakarta: PT. Rineka Cipta, 2000.

[6] Y. Hidayat, Psikologi Olahraga. Bandung: CV. Bintang Warliartika, 2009.

[7] Sugiyono, Metode Penelitian Pendidikan Pendekatan Kuantitatif, Kualitatif, dan R\&D. Bandung: Alfabeta, 2014

[8] B. Tarigan, Pendidikan Jasmani Adaptif. Bandung: UPI PRESS, 2016.

[9] H. Nurhasan and D. Cholil, Tes dan Pengukuran Keolahragaan. Bandung: Universitas Pendidikan Indonesia, 2007.

[10] Widiastuti, Tes dan Pengukuran Olahraga, Jakarta: PT. RAJAGRAFINDO PERSADA, 2015.

[11] Sudijono, Pengantar Statistik Pendidikan. Jakarta: Rajawali Pers, 2009.

[12] R. Susilana and C. Riyana, Media Pembelajaran. Bandung: FIP UPI, 2008

[13] D.L. Lowther, J.D. Russell, S.E. Smaldino, Instructional Technology \& Media For Learning Teknologi Pembelajaran dan Media untuk Belaja (Terjemahan. Edisi Kesembilan). Jakarta: Kencana Prenada Media Group. 2011. 